\title{
Acetaminophen and Metamizole Induce Apoptosis in HT 29 and SW 480 Colon Carcinoma Cell Lines In Vitro
}

\author{
ANIKA C. BUNDSCHERER, MANUELA MALSY, MICHAEL A. GRUBER, \\ BERNHARD M. GRAF and BARBARA SINNER \\ Department of Anesthesiology, University of Regensburg, Regensburg, Germany
}

\begin{abstract}
Background/Aim: The perioperative phase is supposed to be a period with high vulnerability for cancer dissemination. Acetaminophen and metamizole are common analgesics administered during this phase. We investigated the effect of acetaminophen, metamizole and 4-methylaminoantipyrine (MAA) on proliferation and apoptosis of colon carcinoma cell lines (SW 480 and HT 29). Materials and Methods: Proliferation was detected by cell proliferation ELISA BrdU, and apoptosis by Annexin $V$ staining. Cytochrome $c$ and caspase 3, 8 and 9 expression levels were detected by western blot. Results: Acetaminophen, metamizole or MAA caused slight changes in proliferation. Acetaminophen, metamizole or the combination increased apoptosis in both cell lines. All agents decreased caspase 3 and 8 expression in SW480. Acetaminophen decreased caspase 9 expression in both cell lines. Conclusion: In clinically relevant doses, acetaminophen and/or metamizole induce apoptosis in both colon cancer cell lines. Both mitochondrial and death receptor pathways might be involved in acetaminophen-induced apoptosis.
\end{abstract}

For a variety of solid tumors, surgery is the first-line treatment. However, evidence is growing that the perioperative phase is a period with high vulnerability for cancer dissemination (1). The fatal combination of perioperative immunosuppression, release of cancer cells by surgical trauma and enhanced levels of growth factors increase the risk for cancer recurrence during the perioperative period. Traumatization of tumor vessels and surgical manipulation enable cancer cells to enter the circulation (2). The excessive release of growth factors and

Correspondence to: Dr. Anika Bundscherer, Department of Anesthesiology, University of Regensburg, Franz Josef Strauß Allee 11, 93053 Regensburg, Germany. Tel: +49 9419447801, Fax: +49 9419447802, e-mail: anika.bundscherer@ukr.de

Key Words: Cancer, acetaminophen, metamizole, cell proliferation, apoptosis. inbalance between pro- and antiangiogenetic factors during the wound healing process can foster the growth of disseminated cancer cells and micrometastases (2). Also impairment of anticancer surveillance can be detected during the first postoperative days $(3,4)$. Anesthetic and analgesic agents are applied during this high-risk phase for cancer progression. For this reason, it is under discussion, if the selection of a special anesthesia technique or pain therapy regime can influence the oncological outcome of cancer patients (3-5).

The combination of analgesic agents with different mechanisms of action is a recommended concept in perioperative pain management. Acetaminophen, metamizole and NSAIDs are commonly used non-opioid analgesics (6). Results of several studies indicate that NSAIDs reveal anticancer potency by inhibiting cell proliferation, inducing apoptosis and disturbing tumor stroma interaction processes such as angiogenesis and cell migration (7-9). However, if acetaminophen and metamizole exert similar antineoplastic efficiency as NSAIDs has not been well elucidated yet.

The aim of this study was to investigate the effects of acetaminophen, metamizole and its active metabolite 4-methylaminoantipyrine (MAA), on cell proliferation and apoptosis rate of SW 480 and HT29 colon carcinoma cell lines in vitro.

\section{Materials and Methods}

Reagents. Commercially available acetaminophen (Merck, Darmstadt, Germany), metamizole (Fluka, Buchs, Switzerland), MAA and staurosporine (both Sigma-Aldrich, Steinheim, Germany) were used for this study. A stock solution was prepared by dissolving the agents in standard growth medium, final concentrations were achieved by diluting the stock solution with standard growth medium. All solutions were prepared freshly prior to use.

Cell lines. HT 29 and SW 480 colon carcinoma cell lines were purchased from the German Collection of Microorganism and Cell Culture (DSMZ). Standard growth media (RPMI 1640, Pan Biotech, Aidenbach, Germany) for SW 480 and DMEM (Sigma-Aldrich, Steinheim, Germany) for HT 29 contained 10\% Fetal calf serum (FCS) (Sigma Aldrich, Steinheim, Germany) and $2 \mathrm{mM} \mathrm{L-}$ 
Glutamine (Sigma Aldrich, Steinheim, Germany) supplemented with 5\% penicillin plus streptomycin (Sigma Aldrich, Steinheim, Germany). SW 480 culture media additionally contained $2 \mathrm{mM}$ sodium pyruvate (Appli Chem, Darmstadt, Germany). Cells were maintained in monolayer culture and were cultured in a humidified $\mathrm{CO}_{2}$ atmosphere $(5 \%)$ at $37^{\circ} \mathrm{C}$. Experiments were performed when cells reached $\sim 80 \%$ confluence.

Cell proliferation. The cell proliferation ELISA BrdU (Roche applied science, Mannheim, Germany) was used for the detection of cell proliferation rate. In brief, cells (SW $4805 \times 10^{3}$, HT 29 $\left(3 \times 10^{3}\right)$ were seeded in 96-well plates (Costar, Bodenheim, Germany) and incubated overnight to allow attachment. Cells were incubated for $48 \mathrm{~h}$ with acetaminophen $(0-1000 \mu \mathrm{M})$, metamizole $(0-$ $500 \mu \mathrm{M})$ or MAA $(0-500 \mu \mathrm{M})$ and for $16 \mathrm{~h}$ with BrdU labeling solution. After cell fixation and DNA denaturation, cells were labeled with Anti-BrdU-POD solution for $90 \mathrm{~min}$. Cells were washed, incubated with TMB substrate for $15 \mathrm{~min}$ and immune complexes were measured by detecting absorbance at 405 and 490 $\mathrm{nm}$. All tests were performed in duplicates, eight wells per treatment group were used and tests were repeated at least twice.

Apoptosis analysis. SW $480\left(8 \times 10^{5}\right)$ or HT $29\left(3,5 \times 10^{5}\right)$ cells were seeded in T $25 \mathrm{~cm}^{2}$ cell culture flasks (BD Falcon, Heidelberg, Germany). After $24 \mathrm{~h}$ attachment time, cells were incubated with the test agents $(250 \mu \mathrm{M}$ or $1000 \mu \mathrm{M})$ for 3-48 $\mathrm{h}$. One $\mu \mathrm{M}$ staurosporine (Sigma Aldrich, Steinheim, Germany) was used for positive control. Floating cells were preserved by decanting supernatant. Adherent cells were rinsed with PBS $\left(37^{\circ} \mathrm{C}\right)$ (Sigma Aldrich Steinheim, Germany) and detached by standard trypsinization. FITC Annexin V Apoptosis detection kit (BD Bioscience, Franklin Lakes, NJ, USA) was used according to the manufacturer's protocol. In brief, floating and harvested cells were mixed, washed twice with cold PBS and resuspended in binding buffer at a final concentration of $10^{6}$ cells $/ \mathrm{ml} .5 \mu \mathrm{l}$ of FITC Annexin and $5 \mu \mathrm{l}$ of PI were added to $100 \mu \mathrm{l}$ of the cell suspension containing $10^{5}$ cells. After mixing gently, cell suspension was incubated at room temperature in the dark for $15 \mathrm{~min}$. After adding $400 \mu \mathrm{l}$ of binding buffer, cells were analyzed by flow cytometry using FACS Calibur (BD Bioscience, Franklin Lakes, NJ, USA) and Cellquest ${ }^{\mathrm{TM}}$ Pro software (BD Bioscience, Franklin Lakes, NJ, USA). All tests were performed in duplicates and repeated at least twice. For data analysis Fowjo v10.0.7 (Ashland, OR, USA) was applied.

Western blot analysis. Antibodies: For immunoblotting, membranes were probed with antibodies against caspase 3, caspase 8, caspase 9, cytochrome $c$ (Cell signaling, Leiden, the Netherlands), and Bactin (Sigma-Aldrich, Steinheim, Germany).

Subcellular fractionation and immunoblotting: HT 29 and SW 480 cells were either incubated with $1000 \mu \mathrm{M}$ of metamizole, MAA, acetaminophen or a combination of the reagents for $24 \mathrm{~h}$ and 48 h. Standard growth medium was used for negative control, staurosporine $(1 \mu \mathrm{M})$ for positive control. Cells were washed twice with cold DPBS and collected by centrifugation at $4000 \mathrm{rpm}$ at $4^{\circ} \mathrm{C}$ for $10 \mathrm{~min}$. Lysates were then resuspended in RIPAE-Buffer $(5 \mathrm{ml}$ Triton X100, $190 \mathrm{mg}$ EDTA, $0.5 \mathrm{~g}$ SDS, $2.5 \mathrm{~g}$ Deoxycolid Acid, $500 \mathrm{ml}$ DPBS, proteinase inhibitors) for $15 \mathrm{~min}$ and centrifuged at $13.000 \mathrm{rpm}$ for $30 \mathrm{~min}$. Supernatants were transferred to new cups and incubated on ice. $30 \mu \mathrm{g}$ of total lysates were analyzed by SDSPAGE and blotted onto nitrocellulose. After protein extraction and gel transfer, membranes were washed in TBS washing buffer and incubated with peroxidase-conjugated secondary antibodies. Immunoreactive proteins were visualized by means of an enhanced chemiluminescence detection system (Western Blotting Detection Reagent, GE Healthcare, Freiburg, Germany).

Statistical analysis. Results are expressed as mean \pm SD. For comparison between mean values the non-parametric MannWhitney- $U$-test was used. Differences were considered statistically significant at $p<0.05$. IBM SPSS Statistics (V 21; IBM New York, NY, USA) and Excel 2010 (Microsoft, Redmond, WA, USA) packages were employed for statistical analysis.

\section{Results}

Cell proliferation. After incubation with $1,000 \mu \mathrm{M}$ acetaminophen cell proliferation was significantly reduced in SW 480 cells (Figure 1A). Lower concentrations of acetaminophen did not affect SW 480 cell growth. In HT 29 cells, only $1 \mu \mathrm{M}$ acetaminophen caused a slight but significant inhibition of cell proliferation. $1 \mu \mathrm{M}$ metamizole slightly but significantly enhanced cell proliferation rate in SW 480 cell by $5 \% \pm 16 \%$ but inhibited growth of HT 29 cells by $13 \% \pm 1.8 \%$ (Figure 1B). MAA only revealed antiproliferative activity at $500 \mu \mathrm{M}$ in HT29 cells (Figure 1C). All other concentrations of MAA and metamizole did not change proliferation rate (Figure 1).

Apoptosis analysis. Incubation with $250 \mu M$ of the test agents: Incubation with $250 \mu \mathrm{M}$ metamizole enhanced the number of apoptotic cells after $24 \mathrm{~h}$ compared to the untreated control in HT $29(14,3 \% \pm 3,5 \%$ to $17,0 \% \pm 2,6 \%)$ and SW $480(17,6 \% \pm 3.4 \%$ to $21,8 \% \pm 1.6 \%)$ cell lines. The amount of $250 \mu \mathrm{M}$ MAA did not affect the apoptosis rate in both cell lines, $250 \mu \mathrm{M}$ acetaminophen only induced apoptosis in SW 480 colon carcinoma cells after $16 \mathrm{~h}$ and $24 \mathrm{~h}$ treatment time compared to untreated control. The combination of $250 \mu \mathrm{M}$ acetaminophen and metamizole significantly enhanced apoptotic cells in both cell lines after 16 and 24h (HT $2914,3 \% \pm 3,5 \%$ to $17,9 \% \pm 4,7 \%$ and SW $48017,6 \% \pm 3,4 \%$ to $22,2 \% \pm 2,3 \%$ ) (data not shown).

Incubation with $1 \mathrm{mM}$ of the test agents: In SW 480 cell line a significant induction of apoptosis was detected after $24 \mathrm{~h}$ and $48 \mathrm{~h}$ incubation with $1 \mathrm{mM}$ acetaminophen, metamizole as well as the combination of $1 \mathrm{mM}$ acetaminophen with $1 \mathrm{mM}$ metamizole. However, treatment with MAA for 24 and $48 \mathrm{~h}$ did not affect the rate of apoptosis (Figure 2A). In HT 29 colon cancer cells a significant enhancement of apoptosis was caused by $1 \mathrm{mM}$ acetaminophen or metamizole after $24 \mathrm{~h}$ and $48 \mathrm{~h}$ treatment time. Also, an incubation with MAA or the combination of acetaminophen and metamizole induced apoptosis after $24 \mathrm{~h}$ (Figure 2B). The positive control staurosporine increased apoptosis rate in both cell lines (data not shown). 

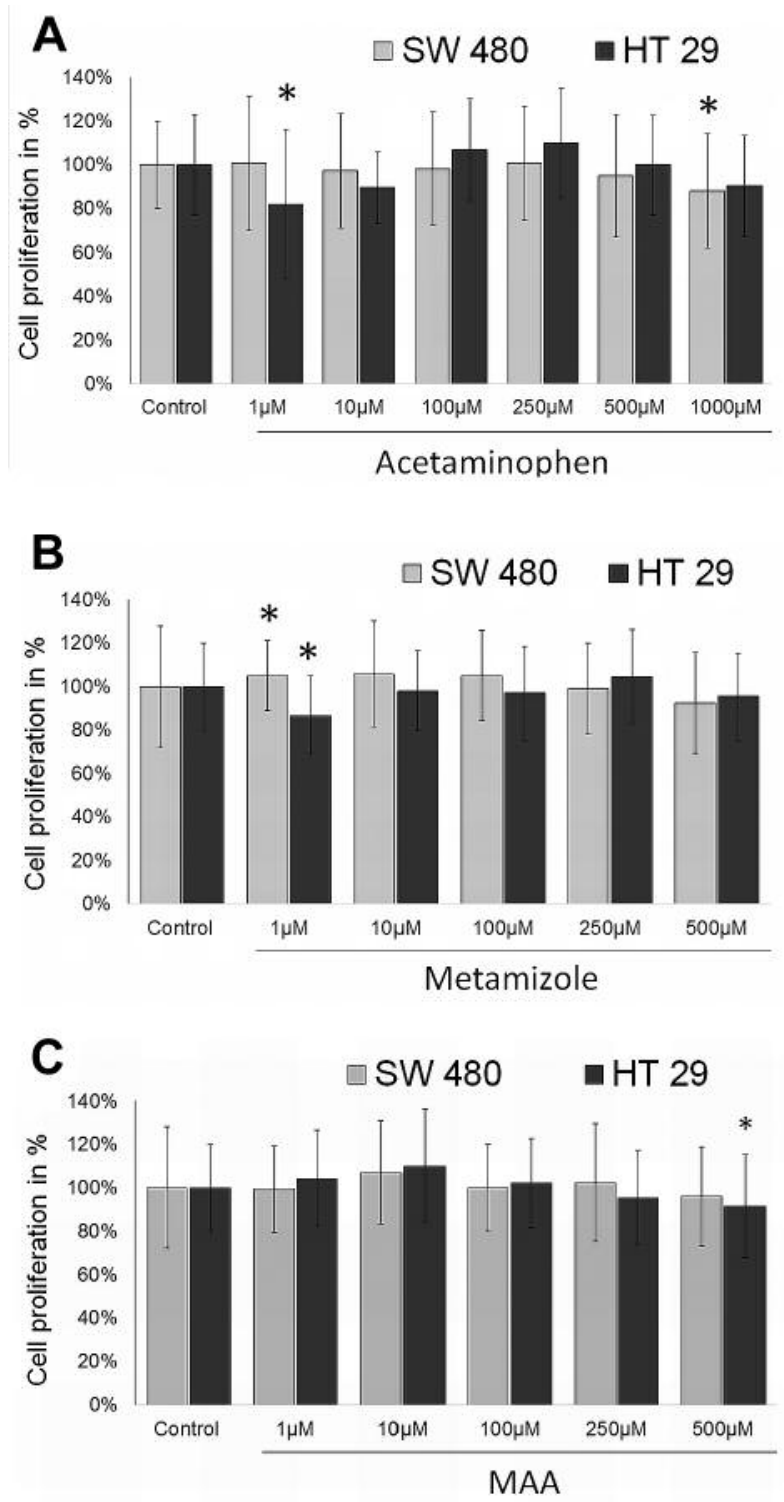

Figure 1. Cell proliferation. Effect of acetaminophen (A), metamizole (B) and MAA (C) on SW480 and HT29 colon carcinoma cell proliferation after $48 \mathrm{~h}$ incubation with 0-1000 $\mu$ M. Proliferation rate was detected by BrdU uptake. *Statistical significance at $p<0.05$ compared to untreated control.

Western blot. Western blot analysis was performed after $24 \mathrm{~h}$ and $48 \mathrm{~h}$ treatment with the test compounds or vehicle. In SW 480 cells a reduction of caspase 3 full length and caspase 8 full length expression was seen after treatment with all test agents. Also, a decrease in procaspase 9 expression occurred after treatment with metamizole, acetaminophen and the combination of acetaminophen and metamizole (Figure 3A). Also in HT29 colon cancer cells all test agents caused a reduction in caspase 3 full length
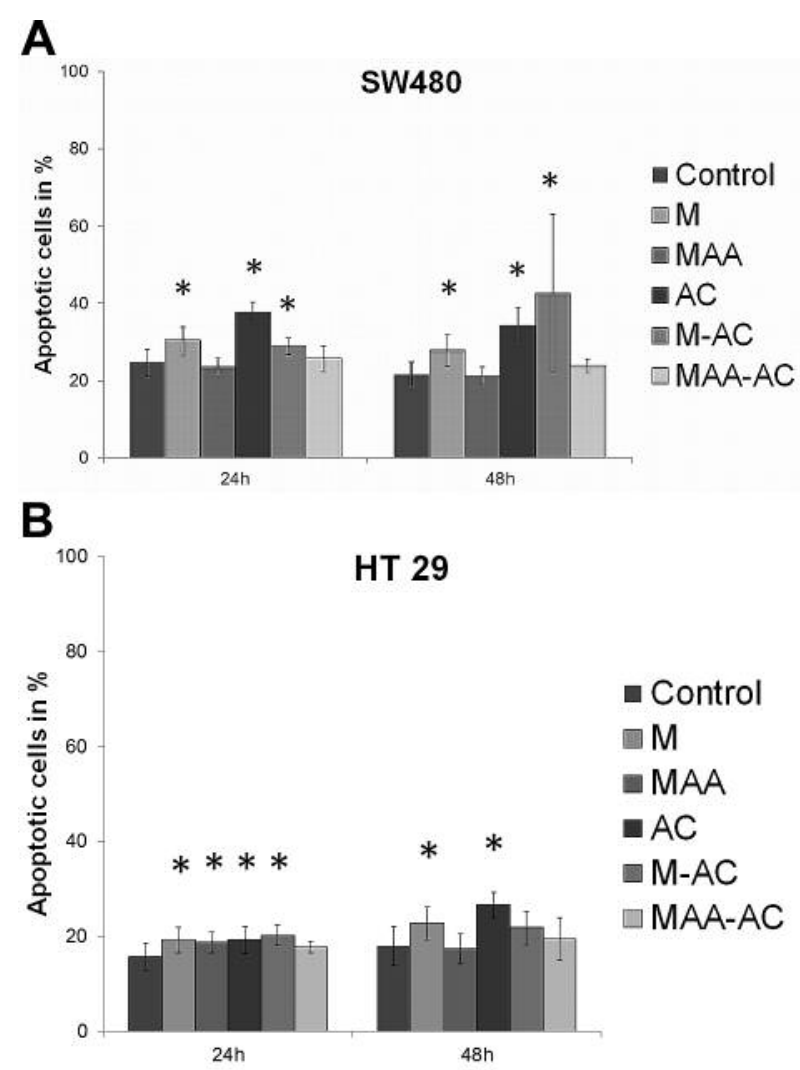

Figure 2. Apoptosis analysis. Effect of $1000 \mu M$ acetaminophen (AC), metamizole $(M), M A A$ or the combination of metamizole + acetaminophen $(M-A C)$ or MAA and acetaminophen (MAA-AC) on apoptosis rate in $S W 480(A)$ and HT29 (B) colon cancer cell lines after 24 and $48 h$ incubation time. *Statistical significance at $p<0.05$ compared to untreated control.

expression level. Caspase 8 full length expression decreased after incubation with acetaminophen and procaspase 9 expression decreased after therapy with acetaminophen, MAA or the combination of both agents (Figure 3B).

\section{Discussion}

Acetaminophen and metamizole are well established nonopioid analgesic agents, which are often used for multimodal postoperative pain therapy. However, the mechanism of action remains unknown. For both agents, interaction with the cannabinoid and opioid system as well as an inhibiton of the cyclooxygenase are discussed $(10,11)$. The pyrazolone derivate metamizole is rapidly hydrolysed to its active metabolite 4-methylaminoantipyrine (MAA). After oral administration of $1 \mathrm{~g}$ metamizole maximal plasma concentration of $17.3 \pm 7.5 \mathrm{mg} / \mathrm{l}$ was measured within 1-2h. Peak plasma concentrations of MAA of $62.2 \pm 15.9 \mathrm{mg} / 1(\sim 210-350 \mu \mathrm{M})$ were obtained after i.v. injection of $1 \mathrm{~g}$ metamizole (12). 


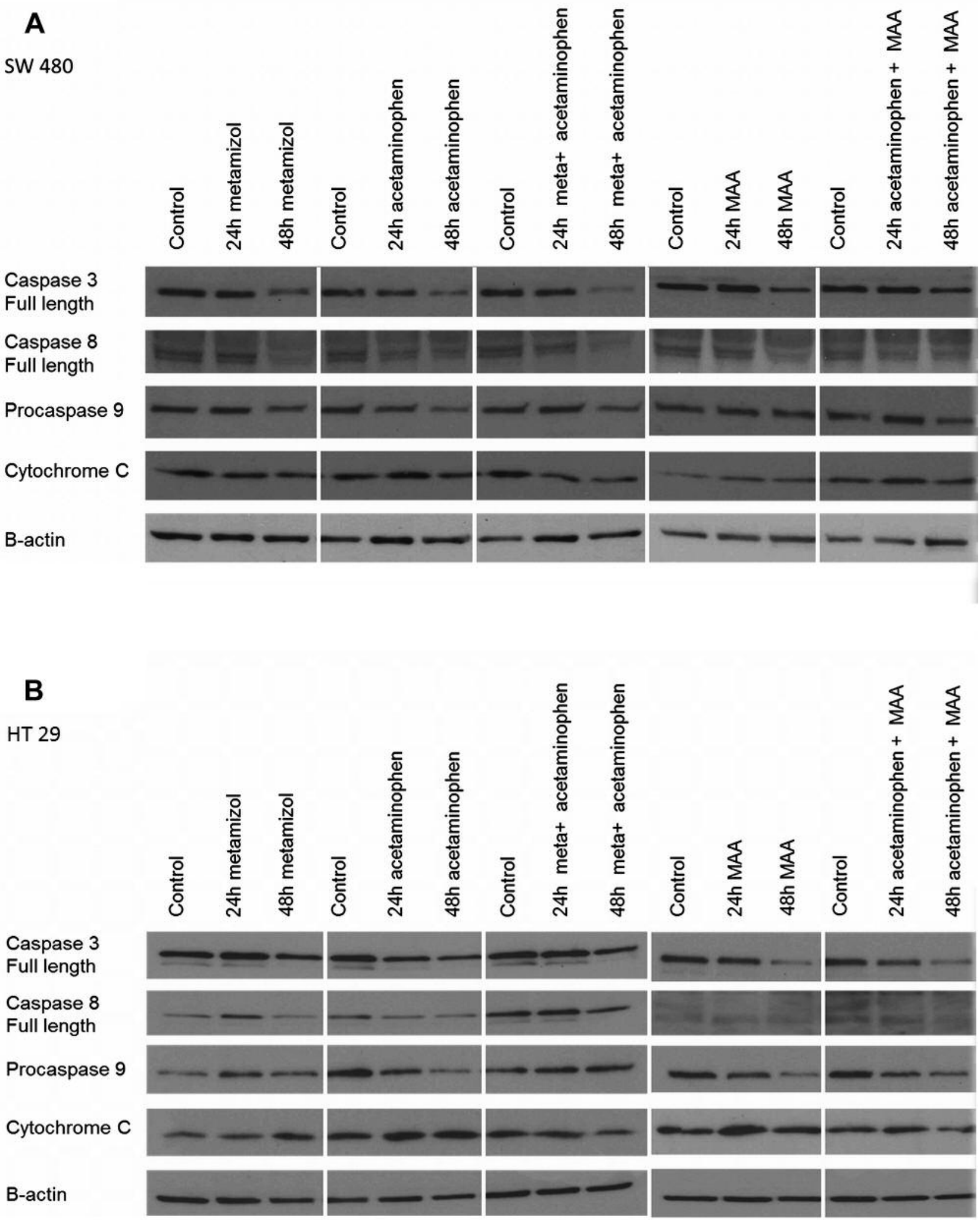

Figure 3. Western blot analysis. Western blot analysis for caspase 3 full length, caspase 8 full length, procaspase 9 , cytochrome c and $\beta$-actin. SW480 (A) and HT 29 (B) cells were treated with $1 \mathrm{mM}$ of metamizole, acetaminophen, MAA or the combination of metamizole and acetaminophen or MAA and acetaminophen for 24 and $48 \mathrm{~h}$. Standard growth medium was used for negative control. 


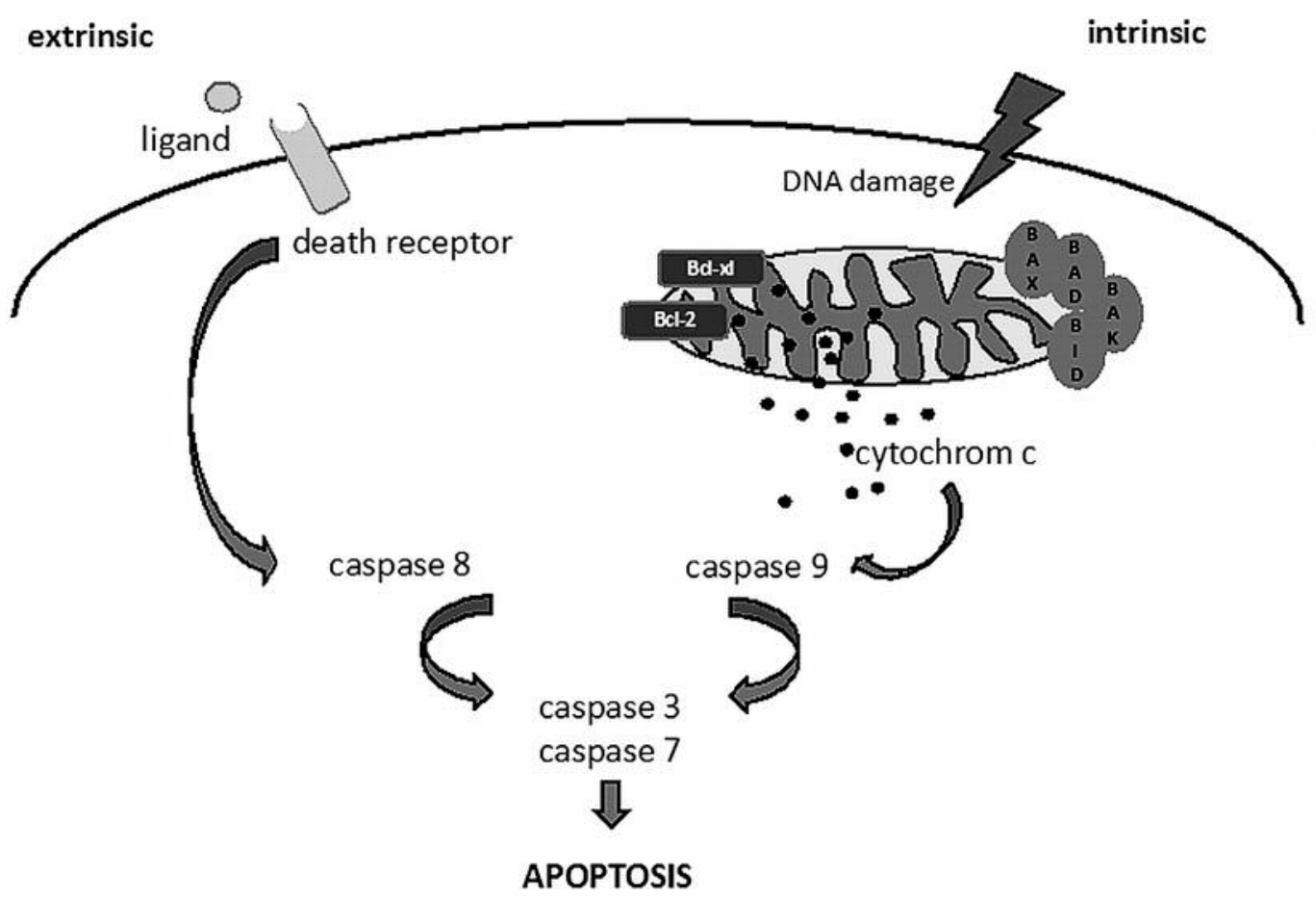

Figure 4. Apoptosis signaling pathway. Extrinsic pathway: activation of caspase 8 after ligand binding to death receptor. Intrinsic (mitochondrial) pathway: activation of caspase 9 after release of cytochrome $c$.

In a pharmacological study, patients undergoing heart surgery received $1 \mathrm{~g}$ acetaminophen every $6 \mathrm{~h}$ either intravenously (i.v.) or rectally. Peak plasma concentrations after the first $i . v$. administration was $95 \pm 36 \mu \mathrm{M}$, after the 4 th i.v. dose concentrations of $210 \pm 84 \mu \mathrm{M}$ were measured, the concentration after the 4 th rectal dose was $69 \pm 44 \mu \mathrm{M}$ (13).

One important characteristic of solid cancer cells is the unlimited cell proliferation. While in healthy tissue cell growth is regulated by a variety of factors, tumor cells develop several mechanisms for evading growth control (14). Results of preclinical studies show that several analgesic agents such as opioids and NSAIDs can affect cancer cell proliferation rate $(8,15,16)$. In this study, we detected only slight effects on cell proliferation by acetaminophen, metamizole and MAA. Metamizole inhibited A549 lung cancer cell proliferation in a dose dependent manner while no induction of apoptotic cell death was detected (17) Clinical concentrations of acetaminophen inhibited cell growth in an epithelial ovarian tumor cell line in vitro (18). Vad et al. reported a selective toxicity of acetaminophen towards melanoma cell lines, while no toxic effects were detected in other tumor entities such as colon and pancreas cancer cell lines (19). However, stimulation of cell proliferation by acetaminophen was observed in lung carcinoma cells (20), kidney fibroblasts (21) and estrogen responsive breast cancer cells (22). Interestingly, coincubation with acetaminophen enhanced sensitivity to chemotherapeutic agents and ionizing radiation (23-25).

Apoptosis is a highly selective process, which plays a crucial role in physiological as well as pathological processes. The programmed cell death can be initiated by two pathways: the intrinsic (or mitochondrial) pathway and the extrinsic (or death receptor) pathway (Figure 4) (26). The extrinsic pathway is started by binding of a ligand to the death receptor. Consecutively, procaspase 8 is cleaved into its activated form. Internal stimuli like hypoxia and irreparable genetic damage can trigger the intrinsic pathway. Due to an increased mitochondrial permeability, the proapoptotic molecule cytochrome $c$ is released into the cytoplasm. This leads to the activation of caspase 9 . The mitochondrial pathway is controlled by proteins of the $\mathrm{Bcl} 2$ family, which are located at the mitochondrial membrane. The sensible balance between pro-apoptotic ( $\mathrm{Bax}, \mathrm{Bad}$ and Bak) and antiapoptotic proteins (Bcl-2, Bcl-xl) is often altered in cancer cells. With the activation of the effector caspase 3 by the initiator caspases 8 and 9 the common pathway of apoptosis is initiated.

In this study we show an induction of apoptotic cell death in clinically relevant doses of metamizole and acetaminophen alone and in combination in HT 29 and SW 480 colon cancer 
cell lines. To elucidate the underlying signaling pathway, drug concentrations were increased to $1 \mathrm{mM}$. In this concentration, a significant induction of apoptosis occurred in SW 480 and HT 29 cells after 24 and $48 \mathrm{~h}$ incubation with metamizole and/ or acetaminophen. As a slight decrease of caspase 9 full length expression level after $48 \mathrm{~h}$ incubation with acetaminophen was detected in both cell lines, the mitochondrial pathway might be involved in acetaminophen induced apoptosis. The coincidental reduction of caspase 8 full length expression level suggests also an involvement of the death receptor signaling pathway.

Posadas et al. showed a potentiation of the staurosporine induced cell death by $1 \mathrm{mM}$ acetaminophen in the human neuroblastoma cell line SH-SY5Y. However, incubation with acetaminophen alone did not cause caspase 3 activation nor cytochrome $c$ release (27). In contrast, higher concentrations (2 $\mathrm{mM}$ ) of acetaminophen induced apoptosis via the mitochondrial pathway (28). Several studies detected an induction of apoptosis via the mitochondrial pathway in different hepatoma cell lines $(21,29,30)$, as well as in neuroblastoma (28). Metamizole attenuated ischemic brain injury and inhibited neuronal cell death via the inhibition of the mitochondrial apoptotic pathway in vivo and in vitro. (31) In three human leukemia cell lines, metamizole revealed cytoprotective effects in low concentrations $(<300 \mu \mathrm{M})$, while in higher concentrations induction of apoptosis was detected (32). Garcia Martinez et al. detected no induction of apoptosis by $75 \mu \mathrm{M}$ metamizole or MAA (33). At concentrations of 10 and $100 \mu \mathrm{M}$ metamizole induced apoptosis in osteoblast like cells and at 1,000 $\mu \mathrm{M}$ necrotic cell death was observed (34).

\section{Conclusion}

Acetaminophen, metamizole and MAA only caused slight changes in cell proliferation in both colon carcinoma cell lines investigated. Results of apoptosis analysis as well as western blot analysis indicated an induction of apoptotic cell death by metamizole and acetaminophen in both cell lines. Due to consumption of procaspase 3,8 and 9 , the induction of apoptosis by acetaminophen seems to follow both an extrinsic and intrinsic signaling pathway. Further studies are warranted to investigate if the combination of acetaminophen and metamizole leads to an augmentation of anticancer effects.

\section{Conflicts of Interest}

None.

\section{Acknowledgements}

The Authors would like to thank Renate Lange, Sigrid Bamberger, Regina Lindner, Marion Schindler, Ruth Spaeth, Theresa Rost and Daniel Potschka (all Department of Anesthesiology, University of
Regensburg, Germany) for their excellent technical support. The Authors would also like to thank the Regensburger Forschungsfoerderung in der Medizin (ReForM) program of the University of Regensburg for financial support.

\section{References}

1 Tavare AN, Perry NJ, Benzonana LL, Takata M and Ma D: Cancer recurrence after surgery: direct and indirect effects of anesthetic agents. Int J Cancer 130: 1237-1250, 2012.

2 Goldfarb Y and Ben-Eliyahu S: Surgery as a risk factor for breast cancer recurrence and metastasis: mediating mechanisms and clinical prophylactic approaches. Breast Dis 26: 99-114, 2006.

3 Snyder GL and Greenberg S: Effect of anaesthetic technique and other perioperative factors on cancer recurrence. $\mathrm{Br} \mathrm{J}$ Anaesth 105: 106-115, 2010

4 Exadaktylos AK, Buggy DJ, Moriarty DC, Mascha E and Sessler DI: Can anesthetic technique for primary breast cancer surgery affect recurrence or metastasis? Anesthesiology 105: 660-664, 2006.

5 Kavanagh T and Buggy DJ: Can anaesthetic technique effect postoperative outcome? Curr Opin Anaesthesiol 25: 185-198, 2012.

6 Pogatzki-Zahn E, Chandrasena C and Schug SA: Nonopioid analgesics for postoperative pain management. Curr Opin Anaesthesiol 27: 513-519, 2014.

7 Akrami H, Aminzadeh S and Fallahi H: Inhibitory effect of ibuprofen on tumor survival and angiogenesis in gastric cancer cell. J Int Soc Oncodevelopment Biol Med 36: 3237-3243, 2015.

8 Leidgens V, Seliger C, Jachnik B, Welz T, Leukel P, VollmannZwerenz A, Bogdahn U, Kreutz M, Grauer OM and Hau P: Ibuprofen and Diclofenac Restrict Migration and Proliferation of Human Glioma Cells by Distinct Molecular Mechanisms. PLoS One 10: e0140613, 2015.

9 Basu GD, Pathangey LB, Tinder TL, Lagioia M, Gendler SJ and Mukherjee P: Cyclooxygenase-2 inhibitor induces apoptosis in breast cancer cells in an in vivo model of spontaneous metastatic breast cancer. Mol Cancer Res 2: 632-642, 2004.

10 Mattia A and Coluzzi F: What anesthesiologists should know about paracetamol (acetaminophen). Minerva Anestesiol 75: 644-653, 2009.

11 Jasiecka A, Maslanka T, and Jaroszewski JJ: Pharmacological characteristics of metamizole. Pol J Vet Sci 17: 207-214, 2014.

12 Aventis S: Fachinformation Novalgin (R), 2011.

13 Holmer Pettersson P, Jakobsson $\mathrm{J}$ and Owall A: Plasma concentrations following repeated rectal or intravenous administration of paracetamol after heart surgery. Acta Anaesthesiol Scand 50: 673-677, 2006.

14 Hanahan D and Weinberg RA: Hallmarks of cancer: the next generation. Cell 144: 646-674, 2011.

15 Basu GD, Pathangey LB, Tinder TL, Gendler SJ and Mukherjee $\mathrm{P}$ : Mechanisms underlying the growth inhibitory effects of the cyclo-oxygenase-2 inhibitor celecoxib in human breast cancer cells. Breast Cancer Res 7: R422-435, 2005.

16 Fujioka N, Nguyen J, Chen C, Li Y, Pasrija T, Niehans G, Johnson KN, Gupta V, Kratzke RA and Gupta K: Morphineinduced epidermal growth factor pathway activation in nonsmall cell lung cancer. Anesth Analg 113: 1353-1364, 2011. 
17 Shao J and Feng G: Selective killing effect of oxytetracycline, propafenone and metamizole on A549 or Hela cells. Chin J Cancer Res 25: 662-670, 2013.

18 Lima RA, Candido EB, de Melo FP, Piedade JB, Vidigal PV, Silva LM and da Silva Filho AL: Gene expression profile of $\mathrm{ABC}$ transporters and cytotoxic effect of ibuprofen and acetaminophen in an epithelial ovarian cancer cell line in vitro. Rev Bras Ginecol Obstet 37: 283-290, 2015.

19 Vad NM, Kudugunti SK, Graber D, Bailey N, Srivenugopal K and Moridani MY: Efficacy of acetaminophen in skin B16-F0 melanoma tumor-bearing C57BL/6 mice. Int J Oncol 35: 193204, 2009.

20 Schonberg SA and Skorpen F: Paracetamol counteracts docosahexaenoic acid-induced growth inhibition of A-427 lung carcinoma cells and enhances tumor cell proliferation in vitro. Anticancer Res 17: 2443-2448, 1997.

21 Yu YL, Yiang GT, Chou PL, Tseng HH, Wu TK, Hung YT, Lin PS, Lin SY, Liu HC, Chang WJ and Wei CW: Dual role of acetaminophen in promoting hepatoma cell apoptosis and kidney fibroblast proliferation. Mol Med Rep 9: 2077-2084, 2014.

22 Gadd SL, Hobbs G and Miller MR: Acetaminophen-induced proliferation of estrogen-responsive breast cancer cells is associated with increases in c-myc RNA expression and NFkappaB activity. Toxicol Sci 66: 233-243, 2002.

23 Casper D, Lekhraj R, Yaparpalvi US, Pidel A, Jaggernauth WA, Werner P, Tribius S, Rowe JD and LaSala PA: Acetaminophen selectively reduces glioma cell growth and increases radiosensitivity in culture. J Neurooncol 46: 215-229, 2000.

24 Bilir A, Guneri AD and Altinoz MA: Acetaminophen and DMSO modulate growth and gemcitabine cytotoxicity in FM3A breast cancer cells in vitro. Neoplasma 51: 460-464, 2004.

25 Neuwelt AJ, Nguyen T, Wu YJ, Donson AM, Vibhakar R, Venkatamaran S, Amani V, Neuwelt EA, Rapkin LB and Foreman NK: Preclinical high-dose acetaminophen with $\mathrm{N}$ acetylcysteine rescue enhances the efficacy of cisplatin chemotherapy in atypical teratoid rhabdoid tumors. Pediatr Blood Cancer 61: 120-127, 2014.

26 Wong RS: Apoptosis in cancer: from pathogenesis to treatment. J Exp Clin Cancer Res 30: 87, 2011.
27 Posadas I, Vellecco V, Santos P, Prieto-Lloret J and Cena V: Acetaminophen potentiates staurosporine-induced death in a human neuroblastoma cell line. Br J Pharmacol 150: 577-585, 2007.

28 Posadas I, Santos P and Cena V: Acetaminophen induces human neuroblastoma cell death through NFKB activation. PLoS One 7: e50160, 2012.

29 Macanas-Pirard P, Yaacob NS, Lee PC, Holder JC, Hinton RH and Kass GE: Glycogen synthase kinase-3 mediates acetaminophen-induced apoptosis in human hepatoma cells. J Pharmacol Exp Ther 313: 780-789, 2005.

30 Kass GE, Macanas-Pirard P, Lee PC and Hinton RH: The role of apoptosis in acetaminophen-induced injury. Ann N Y Acad Sci 1010: 557-559, 2003.

31 Zhang Y, Wang X, Baranov SV, Zhu S, Huang Z, Fellows-Mayle W, Jiang J, Day AL, Kristal BS and Friedlander RM: Dipyrone inhibits neuronal cell death and diminishes hypoxic/ischemic brain injury. Neurosurgery 69: 942-956, 2011.

32 Pompeia C, Boaventura MF and Curi R: Antiapoptotic effect of dipyrone on HL-60, Jurkat and Raji cell lines submitted to UV irradiation, arachidonic acid and cycloheximide treatments. Int Immunopharmacol 1: 2173-2182, 2001.

33 Garcia-Martinez JM, Fresno Vara JA, Lastres P, Bernabeu C, Betes PO and Martin-Perez J: Effect of metamizol on promyelocytic and terminally differentiated granulocytic cells. Comparative analysis with acetylsalicylic acid and diclofenac. Biochem Pharmacol 65: 209-217, 2003.

34 De Luna-Bertos E, Ramos-Torrecillas J, Manzano-Moreno FJ, Garcia-Martinez O and Ruiz C: Effects on growth of human osteoblast-like cells of three nonsteroidal anti-inflammatory drugs: metamizole, dexketoprofen, and ketorolac. Biol Res Nurs 17: 62-67, 2015.
Received November 13, 2017

Revised November 27, 2017

Accepted November 28, 2017 